\title{
Effect of disturbance on fine root biomass in the Tropical moist forest of eastern Nepal
}

\author{
Tilak Prasad Gautam* and Tej Narayan Mandal \\ Department of Botany, Post Graduate Campus, Tribhuvan University, Biratnagar, Nepal \\ EE-mail: tilakg673@gmail.com
}

\begin{abstract}
Fine root biomass ( $<5 \mathrm{~mm}$ diameter) was estimated in $0-15 \mathrm{~cm}$ and $15-$ $30 \mathrm{~cm}$ soil depths of disturbed and undisturbed stands of tropical moist forest in eastern Nepal. The value of root mass was higher $\left(4.28 \mathrm{t} \mathrm{ha}^{-1}\right)$ in the undisturbed stand than the disturbed stand $\left(2.04 \mathrm{t} \mathrm{ha}^{-1}\right)$. The biomass of smaller fine roots $\left(<2 \mathrm{~mm}\right.$ diameter) was 1.51 and $3.2 \mathrm{t} \mathrm{ha}^{-1}$ in the disturbed and undisturbed stands respectively. Most of the fine roots were present in the surface soil layer $(0-15 \mathrm{~cm})$, in both the disturbed and undisturbed stands $(67 \%$ in the disturbed and $64 \%$ in the undisturbed). The nitrogen stock in the fine roots was more $(38.61 \mathrm{~kg}$ $\left.\mathrm{ha}^{-1}\right)$ in undisturbed stand than the disturbed stand $\left(16.93 \mathrm{~kg} \mathrm{ha}^{-1}\right)$. More nitrogen was confined in the fine roots of $<2 \mathrm{~mm}$ diameter in both undisturbed $\left(28.8 \mathrm{~kg} \mathrm{ha}^{-1}\right)$ and disturbed $\left(13.59 \mathrm{~kg} \mathrm{ha}^{-1}\right)$ stands.
\end{abstract}

Key words: Forest, disturbance, fine root biomass, nitrogen stock

\section{Introduction}

In many tropical countries, forest destruction and conversion to agricultural land is continuing at high rate. In the periphery of most tropical forest of Nepal, selective logging and the creation of small-scale crop plantations are significant causes of deforestation. Because the area of disturbed forest increases rapidly, we need a better understanding of the ecological consequences of forest disturbance in the aboveground as well as the belowground system. Research on the structure and functioning of disturbed tropical forests mostly focuses on aboveground aspects only. However, some studies reported the effect of anthropogenic disturbance on the belowground system of tropical forests (Leuschner et al. 2006; Barbhuiya et al., 2012). Moreover, effect of landslide disturbance on the fine root biomass, production and turnover rate has been studied in five age series ( 1 year to 58 yearold) landslide damaged sites in the sal forest ecosystem of Nepal Himalaya (Mandal, 1999).

Fine roots $(<5 \mathrm{~mm}$ in diameter) are responsible for water and nutrient uptake and synthesis of certain growth hormones. Therefore, they have a key role in nutrient and water cycling and soil carbon sequestration in terrestrial ecosystems due to the large carbon input into soil from fine roots and the stabilization of the associated carbon derived from roots (Guo et al., 2007). Fine roots which are dynamic components of below-ground biomass represent about $30 \%$ of the above-ground biomass (Noordwijik et al., 1996) and between 40-85\% of the net primary production according to soil type (Hoffmann \& Usoltsev, 2001). High fine root densities increase the hydraulic contact between plants and the soil, water uptake rates and therefore contribute to higher transpiration rates (Williams et al., 1998).

One of the important factors that may be critically related to root function is soil depth. Soil bulk density, clay content, moisture, nutrient content, temperature, and soil microbial 
biomass composition generally change with soil depth, and root life span is likely affected by these soil properties (Jackson et al., 2000; Joslin et al., 2006). The activity of fine roots in the forest is suggested to be under strong genetic control (Espeleta et al., 2009), but fine roots also show variation in their biomass and vertical distribution in response to environment and stand age (Yuan \& Chen, 2010).

Fine roots also are important sources of detritus within the forest soils and thereby sustain soil biological activity (Pollierer et al., 2007) and also influence soil organic matter and nutrient dynamics (Hendricks et al., 2006). Increased nutrient availability might increase carbon input to soils through enhanced fine root turnover (King et al., 2002). The contribution of fine roots to the carbon and nutrients stock in the soil is equivalent or even higher to that of litterfall that returns carbon and nutrients from canopy to the soil (Hendrick \& Pregitzer, 1993).

Fine roots can fluctuate considerably in biomass, production, and turnover throughout the season or between years, depending on different sites (Wang \& Guo 2008; Barbuhiya et al., 2012). Despite the importance of fine roots, their sampling is more time consuming and the methods are usually less precise. Thus, fine roots remain one of the most challenging but important areas of study in terrestrial ecosystems. Therefore, the studies of fine root dynamics and turnover rate are still essential at present. The main objective of the present study was to evaluate the effect of disturbance on fine root biomass and nitrogen stock in fine root in tropical moist forest (Charkoshe jungle) of eastern Nepal.

\section{Materials and Methods}

\section{Study area}

The present study was conducted in the sal bearing tropical forest (Charkoshe jungle), located in the bhabar belt of Sunsari district, eastern Nepal (Longitude $86^{\circ} 53^{\prime} \mathrm{E}$ to $87^{\circ} 21^{\prime} \mathrm{E}$ and latitude $26^{\circ} 24^{\prime} \mathrm{N}$ to $26^{\circ} 52^{\prime} \mathrm{N}$ ), within the altitude range of 220 to $370 \mathrm{~m}$ above m.s.l. It falls under the tropical moist forest according to the life zone classification of Holdridge et al. (1971). The sampling area was selected at the central core part (which was treated as undisturbed forest stand) and peripheral part of the forest (disturbed stand).

\section{Climate}

The climate is tropical monsoon type. The year is divisible into three distinct seasons: (i) dry and warm summer season (March to May); (ii) wet and warm rainy season (June to October); and (iii) dry and cool winter (November to February). Based on the data for 20072011, mean monthly minimum temperature ranged from $9.3-25.5^{\circ} \mathrm{C}$ and maximum temperature ranged from $22.4-34.5^{\circ} \mathrm{C}$. The average annual rainfall was $1814.9 \mathrm{~mm}$; of which more than $79 \%$ occurred from June to September (Fig. 1). Relative humidity was higher from June to October. Data on rainfall, temperature and humidity were obtained from the Department of Meteorology, Koshi Basin, Dharan in Sunsari district, Nepal.

\section{Soil}

The study area is bordered by Siwalik hills in the north and Gangetic alluvial plains in the south. The area has been formed from soft erodible sediments of the Siwaliks and is identified by the presence of boulder beds mixed with sand, silt, clay forming a porous nature. Topsoil of the study area is typical loam. 


\section{Vegetation}

The forest is dominated by Shorea robusta Gaertn. Other main associates are Lagerstroemia parviflora Roxb., Terminalia alata Heyne ex Roth., Mallotus philippensis (Lam.) Mull.Arg., Adina cordifolia Benth. \& Hook f. ex Bran, Dillenia pentagyna Roxb., Terminalia bellerica (Gaertn.) Roxb., Schleichera oleosa Lour. Merr., Croton roxburghii N.P. Balakr., Careya arborea Roxb. The forest is also the habitat of some rare (e.g. Dalbergia latifolia Roxb., Desmodium oojeinensis (Roxb.) H. Ohashi, Pterocarpus marsupium Roxb. etc.) and commercially as well as medicinally important plants (e.g. Acacia catechu (L.) Willd., Cassia fistula L., Holorrhena antidysenterica Wall., Terminalia chebula Retz. etc.).

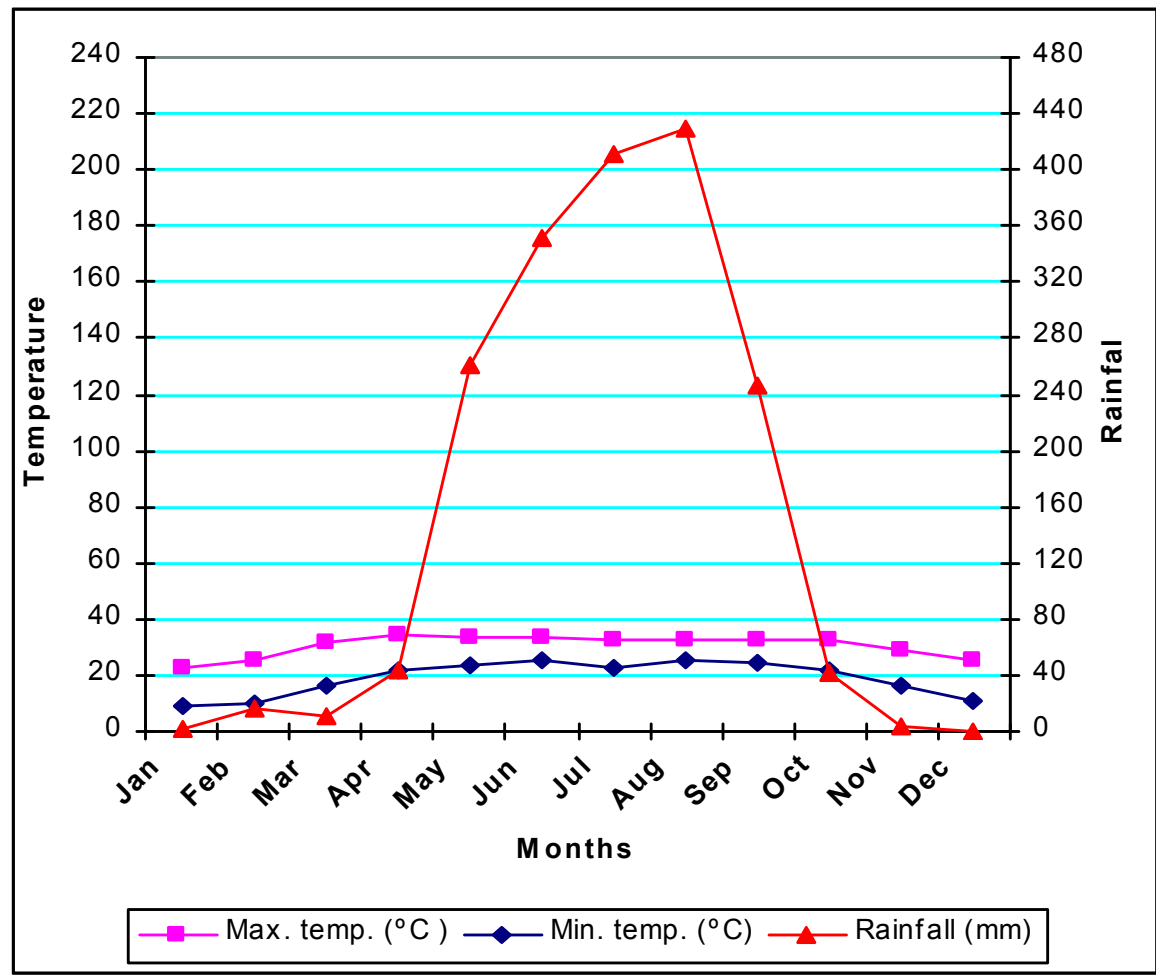

Figure 1. Ombrothermic representation of the climate in tropical moist forest region of eastern Nepal.

\section{Estimation of fine root biomass}

Fine roots $(<5 \mathrm{~mm}$ diameter) were collected during summer season (May, 2011) from one soil monolith $\left(10 \times 10 \mathrm{~cm}^{2}\right)$ within two depth ranges $(0-15$ and $15-30 \mathrm{~cm})$ in thirty five randomly located sites at each stand. Soil monoliths were washed over a sieve with fine jet of water to retrieve the fine roots. They were oven dried at $80^{\circ} \mathrm{C}$ to constant weight and weighed to find the dry matter content. Oven dried fine roots were categorized in $<2 \mathrm{~mm}$ diameter and 2-5 $\mathrm{mm}$ diameter fraction. The root biomass was estimated diameterwise and depthwise.

\section{Nitrogen concentration and Stock}

The fine roots of $<2 \mathrm{~mm}$ and $2-5 \mathrm{~mm}$ of all sample size were mixed separately. The concentration of nitrogen was analyzed diameterwise by micro Kjeldahl method following 
Jackson (1958). Concentration of nitrogen was multiplied with the biomass of fine roots in each diameter class and thus stock of nitrogen in fine root was estimated.

\section{Results}

Spatial variation in root mass

Data on fine root biomass estimated during the summer season are presented in table 1 . The total fine root mass $\left(<5 \mathrm{~mm}\right.$ diameter) was higher $\left(4.28 \mathrm{t} \mathrm{ha}^{-1}\right)$ in the undisturbed stand and lower $\left(2.04 \mathrm{t} \mathrm{ha}^{-1}\right)$ in disturbed stand. The biomass of smaller fine roots $(<2 \mathrm{~mm}$ diameter $)$ was 1.51 and $3.2 \mathrm{t} \mathrm{ha}^{-1}$ in the disturbed and undisturbed stands respectively. Similarly, the biomass of larger fine roots $(2-5 \mathrm{~mm}$ diameter) was almost double in the undisturbed stand $\left(1.09 \mathrm{tha}^{-1}\right)$ than the disturbed one $\left(0.53 \mathrm{tha}^{-1}\right)$.

\section{Vertical distribution of root mass}

Most of the fine roots were present in the surface soil layer $(0-15 \mathrm{~cm})$, in both the disturbed and undisturbed stands (67\% in the disturbed and $64 \%$ in the undisturbed). The sub-surface soil layer $(15-30 \mathrm{~cm})$ had $33-36 \%$ of total fine root mass (Tab. 1). In the vertical distribution also, the biomass of small fine roots $(<2 \mathrm{~mm})$ was higher in surface soil layer in both undisturbed $\left(2.0 \mathrm{t} \mathrm{ha}^{-1}\right)$ and disturbed stand $\left(1.03 \mathrm{t} \mathrm{ha}^{-1}\right)$ than the sub-surface layer.

$\underline{\text { Table 1. Fine root biomass }\left(\mathrm{t} \mathrm{ha}^{-1}\right) \text { in tropical moist forest of eastern Nepal. Values are mean } \pm \mathrm{SE}}$

\begin{tabular}{|c|c|c|c|c|c|c|}
\hline \multirow{3}{*}{ Diameter } & \multicolumn{3}{|c|}{ Disturbed stand } & \multicolumn{3}{|c|}{ Undisturbed stand } \\
\hline & \multicolumn{2}{|c|}{ Soil depth (cm) } & \multirow{2}{*}{ Total } & \multicolumn{2}{|c|}{ Soil depth (cm) } & \\
\hline & $0-15$ & $15-30$ & & $\overline{0-15}$ & $15-30$ & otat \\
\hline$<2 \mathrm{~mm}$ & $1.03 \pm 0.05$ & $0.48 \pm 0.02$ & 1.51 & $2.0 \pm 0.09$ & $1.19 \pm 0.05$ & 3.2 \\
\hline $2-5 \mathrm{~mm}$ & $0.34 \pm 0.02$ & $0.19 \pm 0.01$ & 0.53 & $0.74 \pm 0.08$ & $0.35 \pm 0.05$ & 1.09 \\
\hline Total $(0-5 \mathrm{~mm})$ & $1.37 \pm 0.08$ & $0.67 \pm 0.04$ & 2.04 & $2.74 \pm 0.13$ & $1.54 \pm 0.07$ & 4.28 \\
\hline
\end{tabular}

Nitrogen stock in fine roots

The nitrogen stock in the fine roots was more $\left(38.6 \mathrm{~kg} \mathrm{ha}^{-1}\right)$ in undisturbed stand than the disturbed stand $\left(16.9 \mathrm{~kg} \mathrm{ha}^{-1}\right)$. More nitrogen was confined in the fine roots of $<2 \mathrm{~mm}$ diameter in both disturbed $\left(13.6 \mathrm{~kg} \mathrm{ha}^{-1}\right)$ and undisturbed $\left(28.8 \mathrm{~kg} \mathrm{ha}^{-1}\right)$ stands. The nitrogen stock in the fine roots of $2-5 \mathrm{~mm}$ diameter varied from $19.7-25.4 \%$ of total nitrogen stock in fine roots (Tab. 2).

Table 2. Nitrogen stock in fine root biomass $\left(\mathrm{kg} \mathrm{ha}^{-1}\right)$ in tropical moist forest of eastern Nepal

\begin{tabular}{|c|c|c|c|c|c|c|}
\hline \multirow{3}{*}{ Diameter } & \multicolumn{3}{|c|}{ Disturbed site } & \multicolumn{3}{|c|}{ Undisturbed site } \\
\hline & \multicolumn{2}{|c|}{ Soil depth (cm) } & \multirow{2}{*}{ Total } & \multicolumn{2}{|c|}{ Soil depth (cm) } & \multirow{2}{*}{ Total } \\
\hline & $0-15$ & 15-30 & & $0-15$ & 15-30 & \\
\hline$<2 \mathrm{~mm}$ & 9.27 & 4.32 & 13.59 & 18.09 & 10.71 & 28.8 \\
\hline $2-5 \mathrm{~mm}$ & 2.14 & 1.2 & 3.34 & 6.66 & 3.15 & 9.81 \\
\hline Total (0-5 mm) & 11.41 & 5.52 & 16.93 & 24.75 & 13.86 & 38.61 \\
\hline
\end{tabular}

\section{Discussion}

\section{Spatial variation in fine root biomass}

Fine root biomass was higher in undisturbed stand than the disturbed stand. It may be attributed to differences in site quality and species composition of the vegetation. The higher 
fine root biomass in the undisturbed stand may reflect the higher density and basal area of trees, greater accumulation of surface litter and soil nutrients. Lower root mass in disturbed stand may be attributed to lower organic matter and nutrients. Leuschner et al. (2006) reported that disturbed forest may contain a biomass of fine roots only $60 \%$ or less of the global average in undisturbed tropical moist forests.

\section{Vertical distribution of fine root biomass}

In this study, the fine root biomass decreased with increased soil depth. More than $64 \%$ of the fine root biomass was retrieved in the upper $15 \mathrm{~cm}$ soil layer. This high density of fine roots in the top few centimeters of soil is important for the conservation of nutrients in the forests. Usually, fine root biomass decreases with increased soil depth in many forest types (Borken et al., 2007; Sakai et al., 2007; Zhou \& Shangguan, 2007; Borja et al., 2008). Thus, the vertical distribution of fine roots is a basic strategy that helps plants to acquire belowground nutrients. The greater proportion of roots near the surface in the highly disturbed stand reflected the greater proportion of herbs in the vegetation. This result was similar to observations in a pasture-land of tropical evergreen forest in Mexico (Jaramillo et al., 2003). The biomass of small fine roots $(<2 \mathrm{~mm})$ was higher in surface soil layer in both undisturbed $\left(2.0 \mathrm{t} \mathrm{ha}^{-1}\right)$ and disturbed stands $\left(1.03 \mathrm{t} \mathrm{ha}^{-1}\right)$ than the sub-surface layer. Mandal (1999) also reported higher value $\left(2.3 \mathrm{t} \mathrm{ha}^{-}\right)$of $<2 \mathrm{~mm}$ diameter size fine root in summer season than greater diameter size in Plateau sal forest in eastern Nepal.

\section{Nitrogen stock in fine root}

The nitrogen $(\mathrm{N})$ stock in the fine roots of both stands was significantly higher in surface soil than in deeper soil. This difference in fine root $\mathrm{N}$ content may be related to the trend in the soil $\mathrm{N}$ content. The positive relationship between fine root $\mathrm{N}$ and soil $\mathrm{N}$ was also found in previous study (Helmisaari et al., 2007). The $\mathrm{N}$ stock of fine roots was suggested to be positively related to root respiration (Pregitzer et al., 1998), but negatively related to root longevity (Yuan \& Chen, 2010). The higher fine root N stock at undisturbed stand indicated that soil nutrient absorption in this stand was enhanced by higher root metabolism, while the lower fine root $\mathrm{N}$ stock at disturbed stand was associated with longer longevity of fine roots, which was an optimization of nutrient-poor conditions.

In the present study, nitrogen stock also changed with the diameter of fine roots. More nitrogen concentration was found in the fine roots of $<2 \mathrm{~mm}$ diameter than larger fine roots. Similar trend was described in previous study (Mandal, 1999; Comas \& Eissenstat, 2009).

\section{Acknowledgements}

We are grateful to the Head, Department of Botany and Campus Chief, Post Graduate Campus, Biratnagar for providing laboratory and library facilities. Financial support by the University Grants Commission, Nepal, is thankfully acknowledged.

\section{References}

Barbhuiya, A.R., A. Arunachalam, H.N. Pandey, M.L. Khan \& K. Arunachalam. 2012. Fine root dynamics in undisturbed and disturbed stands of a tropical wet evergreen forest in northeast India. Tropical ecology 53(1): 69-79. 
Borja, I., H.A. De Wit, A. Steffenrem \& H. Majdi. 2008. Stand age and fine root biomass, distribution and morphology in a Norway spruce chronosequence in southeast Norway. Tree physiology 28: 773-784.

Borken, W., G. Kossmann \& E. Matzner. 2007. Biomass, morphology and nutrient contents of fine roots in four Norway spruce stands. Plant Soil 292: 79-93.

Comas, L.H. \& D.M. Eissenstat. 2009. Patterns in root trait variation among 25 co-existing North American forest species. New Phytol 182: 919-928.

Espeleta, J.F., J.B. West \& L.A. Donovan. 2009. Tree species fine-root demography parallels habitat specialization across a sandhill soil resource gradient. Ecology 90: 1773-1787.

Guo, L.B., M. Wang \& R.M. Gifford. 2007. The change of soil carbon stocks and fine root dynamics after land use change from a native pasture to a pine plantation. Plant Soil 299: $251-262$

Helmisaari, H.L. 2007. Roots and carbon allocation- quantity, quality and controls. Rootrap session: belowground carbon turnover in European forests, Finish Forest Research Institute.

Hendrick, R.L., \& K.S. Pregitzer. 1993. The dynamics of fine root length, biomass and nitrogen content in two northern hardwood ecosystems. Canadian Journal of Forest research 23: 2507-2520.

Hendricks, J.J., R.L. Hendrick, C.A. Wilson, R.J. Michell, S.D. Pecot \& D. Guo. 2006. Assessing the patterns and controls of fine root dynamics: An empirical test and methodological review. Journal of Ecology 94: 40-57.

Hoffmann, C.W. \& V.A. Usoltsev. 2001. Modelling root biomass distribution in Pinus sylvestris forests of the Turgai depression of Kazakhstan. Forest Ecology and Management 149: 103-114.

Holdridge, L.R., W.C. Grenke, W.H. Hatheway, T. Liang \& J.A. Jr. Tosi. 1971. Forest Environments in Tropical Life Zones: A Pilot Study. Pergamon Press, Oxford, England.

Jackson, M.L. 1958. Soil Chemical Analysis. Printice Hall, Englewood Cliffs, New Jersey.

Jackson, R.B., H.J. Schenk, E.G. Jobbagy, J. Canadell, G.D. Colello, R.E. Dickinson, C.B. Field, P. Friedlingstein, M. Heimann, K. Hibbard, D.W. Kicklighter, A. Kleidon, R.P. Neilson, W.J. Parton, O.E. Sala \& M.T. Sykes. 2000. Belowground consequences of vegetation change and their treatment in models. Ecological Applications 10: 470-483.

Jaramillo, V.J., R.A. Hernandez \& J.B. Kauffman. 2003. Root biomass and carbon in a tropical evergreen forest of Mexico: changes with secondary succession and forest conversion to pasture. Journal of Tropical Ecology 19: 457-464.

Joslin, J.D., J.B. Gaudinski, M.S. Torn, W.J. Riley \& P.J. Hanson. 2006. Fine-root turnover patterns and their relationship to root diameter and soil depth in a C14-labeled hardwood forest. New Phytol 172: 523-535.

King, J.S., T.J. Albaugh, H.L. Allen, M. Buford, B.R. Strain \& P. Dougherty. 2002. BelowGround carbon input to soil is controlled by nutrient availability and fine root dynamics in loblolly pine. New Phytologist 154: 389-398.

Leuschner, C., M. Wiens, M. Harteveld, D. Hertel \& S. Tjitrosemito. 2006. Patterns of fine root mass and distribution along a disturbance gradient in a tropical montane forest, Central Sulawesi (Indonesia). Plant and Soil 283: 163-174.

Mandal, T.N. 1999. Ecological analysis of recovery of landslide damaged Sal forest ecosystem in Nepal Himalaya. Ph.D. Thesis, Banaras Hindu University, Varanasi, India. 
Noordwijik, M., van G. Lawson, A. Soumare, J.J.R. Groot \& K. Hairiah. 1996. Root distribution of trees and crops: Competition and/or complementarit. In: Tree-Crop interactions: A physiological approach (Eds. C.K. On \& P. Huxley). CAB International, Washington, Oxon, GB, 386 S. pp. 319-364.

Pollierer, M.M., R. Lange, C. Korner, M. Maraun, \& S. Scheu. 2007. The underestimated importance of belowground carbon input for forest soil animal food webs. Ecology Letter 10: 729-736.

Pregitzer, K.S., M.J. Laskowski, A.J. Burton, V.C. Lessard \& D.R. Zak. 1998. Variation in sugar maple root respiration with root diameter and soil depth. Tree Physiology 18: 665670.

Sakai, Y., M. Takahashi \& N. Tanaka. 2007. Root biomass and distribution of a Picea-Abies stand and a Larix-Betula stand in pumiceous Entisols in Japan. Journal of Forestry Research 12: 120-125.

Wang, Z.Q. \& D.L. Guo. 2008. Root ecology. Journal of Plant Ecology 32: 1213-1216.

Williams, M., Y. Malhi, A.D. Nobre, E.B. Rastetter, J. Grace \& M.G.P. Pereira. 1998. Seasonal variation in net carbon exchange and evapotranspiration in a Brazilian rain forest: a modelling analysis. Planr Cell Environ 21: 953-968.

Yuan, Z.Y. \& H.Y.H. Chen. 2010. Fine root biomass, production, turnover rates, and nutrient Contents in Boreal Forest ecosystems in relation to species, climate, fertility, and stand age: literature review and meta-analyses. Crit Review of Plant Science 29: 204-221.

Zhou, Z.C. \& Z.P. Shangguan. 2007. Vertical distribution of fine roots in relation to soil factors in Pinus tabulaeformis Carr. Forest of the Loess Plateau of China. Plant Soil 291: 119129. 